\title{
Static and Dynamic Analyses of Dahr El Baidar Slope
}

\author{
T. Matar' ${ }^{1}$, F. Hage Chehade ${ }^{2}$, J. Harb ${ }^{3}$, \\ M. Rahhal ${ }^{4}$, D. Youssef Abdel Massih ${ }^{5}$, C. Abdallah ${ }^{6}$, E. Ibrahim ${ }^{7}$, L. Khalaf-Keyrouz ${ }^{8}$, \\ G. Nasr' ${ }^{9}$ G. Abou-Jaoude ${ }^{10}$, and A. Sursock ${ }^{11}$ \\ ${ }^{1}$ Lebanese U., F. of Eng., Modeling Center, Doctoral School of S. and T., Lebanon, therese.matar@ gmail.com \\ ${ }^{2}$ Lebanese University, Modeling Center, Doctoral School of S. and T., Lebanon, fchehade@ul.edu.lb \\ ${ }^{3}$ Notre Dame University Louaize, Lebanon, jharb@ ndu.edu.lb \\ ${ }^{4}$ Saint Joseph University, ESIB, Lebanon, muhsin.rahal@usj.edu.lb \\ ${ }^{5}$ Lebanese University, Faculty of Engineering II, Roumieh, Lebanon, dalia.abdelmassih@ul.edu.lb \\ ${ }^{6}$ Lebanese National Council For Scientific Research, Remote Sensing Center, Lebanon, chadi@cnrs.edu.lb \\ ${ }^{7}$ Notre Dame University Louaize, Lebanon, eibrahim@ndu.edu.lb \\ ${ }^{8}$ Notre Dame University Louaize, Lebanon, 1 khalaf@ ndu.edu.lb \\ ${ }^{9}$ Lebanese University, Faculty of Engineering II, Roumieh, Lebanon, george.j.nasr@gmail.com \\ ${ }^{10}$ Lebanese American University, Beirut, Lebanon. grace.aboujaoude@lau.edu.lb \\ ${ }^{11}$ Lebanese National Council For Scientific Research, Geophsyical Center, Lebanon, asursock@cnrs.edu.lb
}

Keywords: slope stability, seismic movement, failure, geotechnical investigation, geophysical tests, correlation, soil properties, dynamic response.

\begin{abstract}
The slope of Dahr El Baidar located on the central mountain of Lebanon hosts a section of the Arab Highway that is under construction to connect Beirut to neighboring Arab countries. This slope has experienced several failures; yet most involved geotechnical companies have investigated the slope with classical geotechnical procedures. In this paper, the analysis of the slope is performed using an integrated geo-assessment approach to identify the principal causes of failure and understand its dynamic behavior. The study includes geological, geophysical and geotechnical soil characterization of the designated area. The geological analysis reveals the presence of faults in the vicinity, in addition to a layer of weak clay at the surface. The geotechnical investigation is based on the interpretation of several boreholes. Geophysical tests are performed using ambient noise vibration technique in order to reveal the resonant frequency and thickness of the soil deposit material. A correlation between geotechnical and geophysical tests was used to establish soil properties in the studies. The above data is used towards a better understanding of the cause and occurrence of the failing zone. A dynamic analysis is conducted to determine the slope amplification and compare the simulated frequencies with the measured ones.
\end{abstract}


T. Matar ${ }^{1}$, F. Hage Chehade ${ }^{2}$, Jacques

$\mathrm{Harb}^{3}$, M. Rahhal ${ }^{4}$, D. Youssef Abdel Massih ${ }^{5}$, C. Abdallah ${ }^{6}$, E. Ibrahim ${ }^{7}$, L. Khalaf-Keyrouz ${ }^{8}$, G. Nasr ${ }^{9}$, G. Abou-Jaoude ${ }^{10}$, and A. Sursock ${ }^{11}$

\section{INTRODUCTION}

Estimations over the last 40 years indicate that mass movements cost each year 10-15 millions of US dollars in this small country (Lebanon) with numerous fatalities and injuries (Khawlie, 2000). Cracks in houses and roads, destruction of agricultural terraces, and scarps of different sizes are very common. Minor movements occurred in other years. Climatic and geological parameters combined with human modifications of land act simultaneously towards increasing mass movements in Lebanon.

As geological parameters have major influence in land movements, some of these large movements in Lebanon have been correlated with major earthquakes. On the other hand, climatic conditions also play an important role whereas, for example, periods of heavy precipitation in the mid to late winter season trigger landslides. Another major parameter affecting land movement is extensive man-induced activities and land alterations such as road and residential construction, deforestation, quarrying, or changing the water regime in irrigation and drainage diversion. Chaotic and rapid urban growth, which is spread throughout the country, is one of the principal causes of natural resource depletion that induces natural hazards such as desertification, mass movement, flash floods, etc. Studies dealing with mass movements (MM) in Lebanon seem to be few and mostly descriptive, yet a few cited works tackled the problem. The first to talk about landslides in Lebanon was Dubertret (1945). He included some description on landslides in the various texts "Notice de la Carte Géologique". He delineated different types of landslides, rock falls and mudflows. Tavitian (1974) studied the Aquoura earthflow giving the engineering properties of the materials and slope stability. Khawlie and Hassanain (1984) studied the phenomenon over several areas in Lebanon giving the types and distinctive features of various occurrences. They related it to different natural and human causes, interpreting both its geological and engineering dimensions. Other studies have dealt indirectly with the subject focusing on instability of surficial materials, e.g. the engineering geological evaluation of marls (Khawlie and Ghalayini, 1985), or the analysis of the terrain and materials in assessing stability of highways (Khawlie and A'war, 1992), or the inherent lithological and geotechnical variability of the basal Cretaceous sandstone (Khawlie and Touma, 1993). The majority of previously mentioned studies treated mass movement phenomenon depending on field work purposes. Sadek, et al., (1999) has started with preliminary and simple modeling for assessing road instability in their studies related to mass movement hazards and slope stability. Rahhal et al. (2003) and Rahhal (2014) discussed the factors triggering slope instabilities in Lebanese mountains, as well as the determination of factors of safety for slopes under earthquake loading. Abdallah et al, (2005) used univariate statistical correlations to determine simple relations between classes of terrain parameters and mass movement occurrence. Youssef Abdel Massih et al. (2007), (2010) have used finite element and finite difference methods for evaluating the stability of some slopes. Several other techniques based on satellite images (Abdallah et al. 2007) were used for assessing mass movement hazard in Lebanon.

In the continuity with the geo-assessment of Dahr el Baidar slope made by Rahhal et al. (2014),, this paper presents static and dynamic stability analyses of Dahr El Baidar slope in Lebanon. The first objective of this research is to understand the causes that lead to slope failure using geotechnical and geophysical investigations. Then, 2D and 3D finite element and finite difference models are used to check the behavior of the slope under earthquake conditions. 
T. Matar ${ }^{1}$, F. Hage Chehade ${ }^{2}$, Jacques

$\mathrm{Harb}^{3}$, M. Rahhal ${ }^{4}$, D. Youssef Abdel Massih ${ }^{5}$, C. Abdallah ${ }^{6}$, E. Ibrahim ${ }^{7}$, L. Khalaf-Keyrouz ${ }^{8}$, G. Nasr ${ }^{9}$, G. Abou-Jaoude ${ }^{10}$, and A. Sursock ${ }^{11}$

\section{SITE LOCATION}

Dahr El Baidar is located at $33^{\circ} 48^{\prime} 18^{\prime \prime} \mathrm{N} 35^{\circ} 45^{\prime} 42^{\prime \prime} \mathrm{E}$ on the slope of a mountainous area in the center of Lebanon. The site is hosting a portion of the "Pan Arab Highway", a main road connecting the coastal zone to the Bekaa valley reaching east the Lebanese Syrian border. It is a vital infrastructure project that has been delayed at several instances due to slope stability problems. In-spite of the numerous geotechnical investigations, this particular site still presents a challenge to designers and contractors as a result of its complexity.

\section{SOIL INVESTIGATION}

\subsection{Geology and tectonic of the region}

The major tectonic features in Lebanon surrounding Dahr El-Baidar are (i) the Yammouneh Fault which is part of the Levantine fault extending from the Aquaba golf, passing by the Jordan valley and Dead Sea, Bekaa valley and north to the Taurus Zaghros Mountains of Turkey; (ii) the Roum Fault which is a branching of the Levantine Yammouneh fault starting from Roum village South, and extending North-West up to the capital Beirut and (iii) the Occidental flexures parallel to the Yammouneh fault regrouping a multitude of minor faults with variable activities. The Dahr el-Baydar slope is located on the center of Mount Lebanon, in a zone distanced around 5 kilometers from the Yammouneh fault, $31 \mathrm{~km}$ from the coastal line and 26 $\mathrm{km}$ from the Roum fault. The area is characterized by a significant tectonic activity. The plateau of Dahr El Baidar is a rock formation ranging from the lower to middle cretaceous $\left(\mathrm{C}_{1}\right.$ to $\mathrm{C}_{3}$ respectively); around $6 \mathrm{~km}$ west of the Yammouneh fault (Dubertret, 1945). This area is positioned in a subducted zone, bounded by two minor East-West faults and highly scattered by other minor faults connected to the Yammoueh fault. The predominant ones are (i) The KabEliasWadi El-Delm fault, $3.5 \mathrm{~km}$ south in the East-West direction, limiting the Jurassic plateau of Jabal El Barouk against the depression of Dahr El Baidar, (ii) a portion of the Yammouneh fault extending around $6 \mathrm{~km}$ oriented NNE-SSW to the East, and (iii) a $2 \mathrm{~km}$ stretch of Jabal El Roueiss fault in the E-W orientation. The system of faults is active however, their individual activity is difficult to trace due to the lack of instrumentation on site and close vicinity.

\subsection{Geotechnical and Geophysical investigation}

Aiming to study the most probable cause of the slopes failure in this region, an experimental campaign was carried out. Eight geotechnical boreholes were drilled in the area (Noted AB in Figure 1).

Table 1 shows the location (coordinates, and altitude) of the different boreholes, as well as the depth reached.

Twelve HVSR (or H/V) ambient vibration tests (Nogoshi and Igarashi (1971), Nakamura (1989)) were conducted on Dahr El Baidar site (Noted by a pin in Figure 1) using Lennartz-5s velocimeters (cut-off period of 5 seconds) connected to a CityShark ${ }^{\mathrm{TM}}$ acquisition unit (Chatelain et al., 2000) with a $200 \mathrm{~Hz}$ sampling rate.

Geopsy software (http://www.geopsy.org; Wathelet et al. 2008) is used to compute the H/V spectral ratios of the registered ambient noise at several locations. A b-value of 40 was used in the smoothing procedure of Konno \& Ohmachi (1998) for the computed Fourier amplitude spectra. The two horizontal components (North-South and East-West) are then combined by computing the quadratic mean and $\mathrm{H} / \mathrm{V}$ ratios calculated by averaging the $\mathrm{H} / \mathrm{V}$ ratios obtained 
T. Matar ${ }^{1}$, F. Hage Chehade ${ }^{2}$, Jacques

Harb $^{3}$, M. Rahhal ${ }^{4}$, D. Youssef Abdel Massih ${ }^{5}$, C. Abdallah ${ }^{6}$, E. Ibrahim ${ }^{7}$, L. Khalaf-Keyrouz ${ }^{8}$, G. Nasr ${ }^{9}$, G.

Abou-Jaoude ${ }^{10}$, and A. Sursock ${ }^{11}$

on individual 10s windows. The peak observed at the $\mathrm{H} / \mathrm{V}$ spectrum will be considered as the natural frequency of the soil at the location of the test.

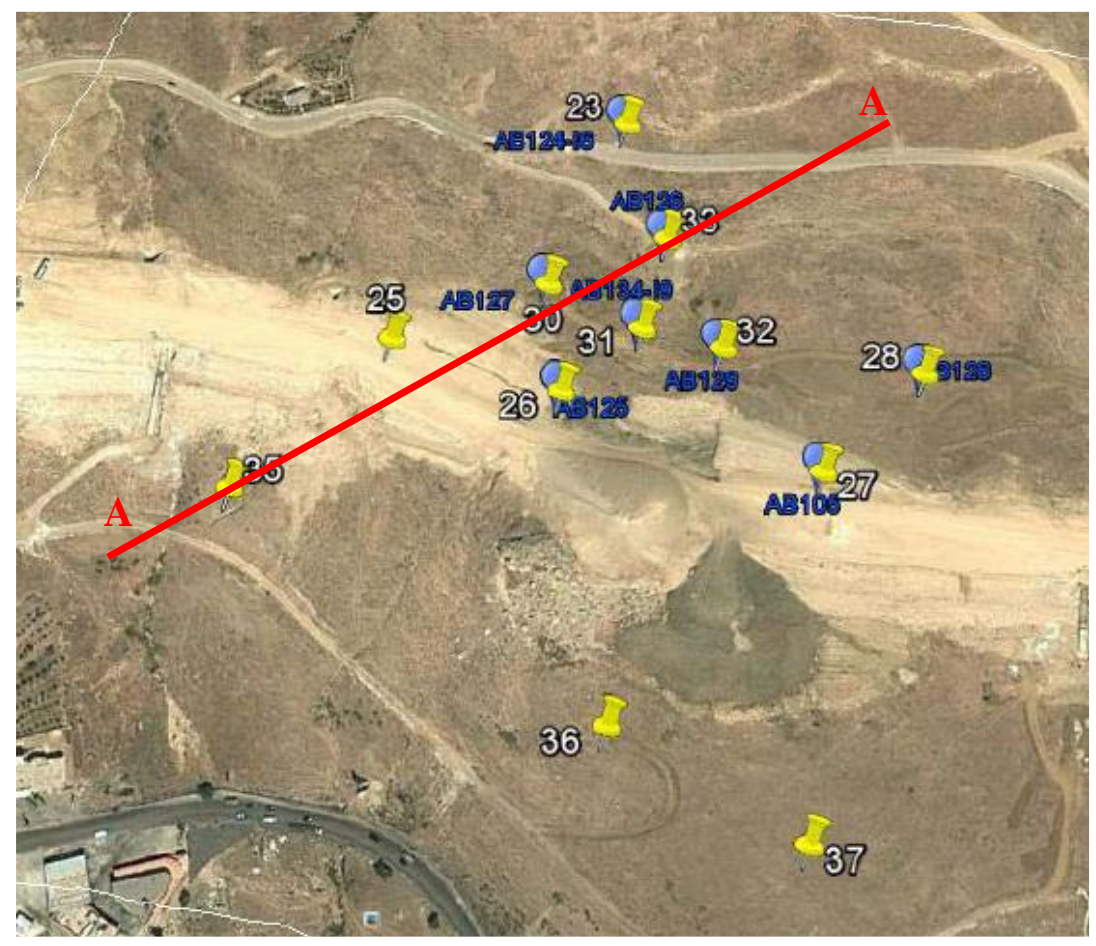

Figure 1: Site Location (from Google earth) including the location of the Pan Arab Highway, HVSR tests and Boreholes.

Table 1: Borehole Local Coordinates, Altitude, Depth reached and date realized.

\begin{tabular}{|c|c|c|c|c|}
\hline Borehole & Local X & Local Y & $\begin{array}{c}\text { Altitude above } \\
\text { sea level (m) }\end{array}$ & $\begin{array}{c}\text { Depth } \\
(\mathbf{m})\end{array}$ \\
\hline AB 105 & -310399.52 & -38422.13 & 1313.83 & 16 \\
\hline AB 125 & -310528.57 & -38393.22 & 1322.18 & 20 \\
\hline AB 126 & -310482.90 & -38314.05 & 1350.21 & 35 \\
\hline AB 127 & -310539.69 & -38340.86 & 1338.52 & 30 \\
\hline AB 128 & -310352.51 & -38369.13 & 1321.38 & 30 \\
\hline AB 129 & -310452.10 & -38366.86 & 1333.07 & 30 \\
\hline AB 134 & -310491.86 & -38360.21 & 1337.96 & 20 \\
\hline
\end{tabular}

\section{GEOTECHNICAL AND GEOPHYSICAL DATA ANALYSIS}

\subsection{Geotechnical Results}

In section A-A (Figure 2), the water table is deep and the following soil layers and properties are considered: At the surface, a marly fill is found next to the crack line. Then, cemented brown sand with presence of clay of low plasticity $(C L)$ is identified with the following shear strength properties (an effective cohesion $c^{\prime}=44 \mathrm{kPa}$ and an effective friction angle $\phi^{\prime}=17^{\circ}$, a plasticity 
T. Matar ${ }^{1}$, F. Hage Chehade ${ }^{2}$, Jacques

$\mathrm{Harb}^{3}$, M. Rahhal ${ }^{4}$, D. Youssef Abdel Massih ${ }^{5}$, C. Abdallah ${ }^{6}$, E. Ibrahim ${ }^{7}$, L. Khalaf-Keyrouz ${ }^{8}$, G. Nasr $^{9}$, G.

Abou-Jaoude ${ }^{10}$, and A. Sursock ${ }^{11}$

index of PI=18\%, and a Standard Penetration Test number SPT N =11). Below, a clayey sand is found $\left(\mathrm{c}^{\prime}=26 \mathrm{kPa}\right.$ and $\phi^{\prime}=25.8^{\circ}, \mathrm{PI}=14 \%$, and SPT $\left.\mathrm{N}=21\right)$. A greyish marl and limestone (with pressumeter results giving Limit Pressure $\mathrm{P}_{1}=2.7 \mathrm{MPa}$ and Menard elastic modulus $\mathrm{E}_{\mathrm{m}}$ $=43.5 \mathrm{MPa}$ ) is interbedded between two clay layers with different properties: the upper clay has a $\mathrm{P}_{1}=420 \mathrm{kPa}$, and $\mathrm{E}_{\mathrm{m}}=3.3 \mathrm{MPa}$, while the lower clay has a $\mathrm{P}_{1}=2.8 \mathrm{MPa}$ and $\mathrm{E}_{\mathrm{m}}=163$ $\mathrm{MPa}$. In depth, marl with different colors (brown, grey and beige) is found with $\mathrm{P}_{1}=3.9 \mathrm{MPa}$ and $\mathrm{E}_{\mathrm{m}}=121 \mathrm{MPa}$. Below, Marly Sandstone is identified

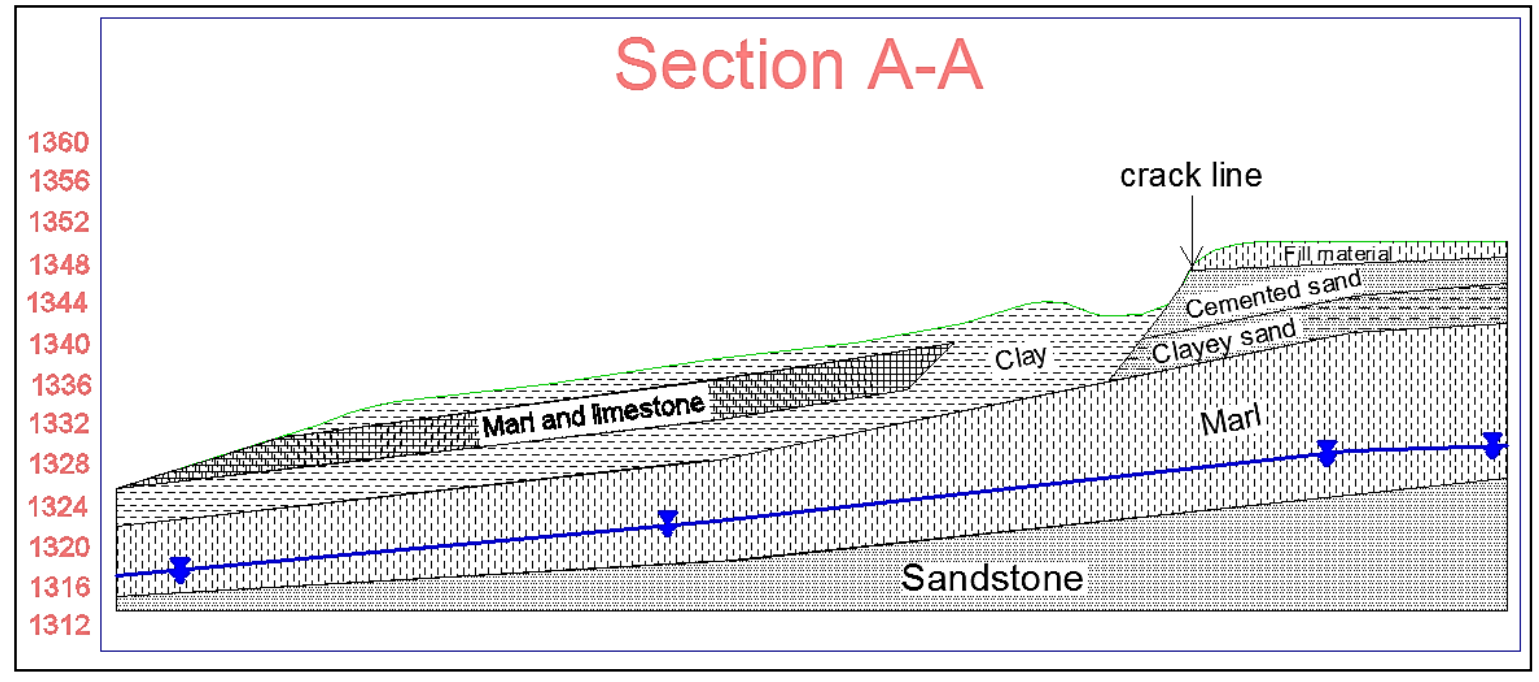

Figure 2: Soil Layers in section $\mathbf{A}-\mathbf{A}$

\subsection{HVSR Geophysical Results}

Due to the site heterogeneity, no clear $\mathrm{H} / \mathrm{V}$ peak frequency is observed at some points. However, a dominant frequency $\mathrm{f}_{0}$ between 3 and $5.5 \mathrm{~Hz}$ is noticed on most of the $\mathrm{H} / \mathrm{V}$ measurements. The estimated $\mathrm{f}_{0}$ from the HVSR measurements at the borehole locations with the corresponding depth D of soft soil to the stiffer layer are reported on Table 2. Equation 1 is used:

$$
f_{\mathrm{o}}=\frac{V_{S}}{4 H}
$$

Where

$\mathrm{f}_{0}$ is the fundamental soil frequency

$\mathrm{H}$ is the depth of the soft layer to the bedrock

$\mathrm{V}_{\mathrm{s}}$ is shear wave velocity of the softer layer

For values of Table 2, the shear wave velocity will range from $100 \mathrm{~m} / \mathrm{s}$ to $300 \mathrm{~m} / \mathrm{s}$.

\section{STATIC ANALYSIS ON THE SITE}

A static analysis of Dahr El Baidar slope is performed using Plaxis software (Vermeer \& Brinkgreve, 1998) based on the Mohr-Coulomb model material for soil behavior. Section A (Figure 2) with same coordinates presented in the geotechnical study is modeled hereafter. Soil properties shown in table 3 based on available soil data are used in the model. 
T. Matar ${ }^{1}$, F. Hage Chehade ${ }^{2}$, Jacques

$\mathrm{Harb}^{3}$, M. Rahhal ${ }^{4}$, D. Youssef Abdel Massih ${ }^{5}$, C. Abdallah ${ }^{6}$, E. Ibrahim ${ }^{7}$, L. Khalaf-Keyrouz ${ }^{8}$, G. Nasr $^{9}$, G. Abou-Jaoude ${ }^{10}$, and A. Sursock ${ }^{11}$

Table 2: $\mathrm{f}_{0}$ and shear wave velocity

\begin{tabular}{|c|c|c|c|c|}
\hline $\begin{array}{c}\text { HVSR } \\
\text { tests }\end{array}$ & $\begin{array}{c}\text { Bore- } \\
\text { hole }\end{array}$ & fo (Hz) & $\mathbf{D}(\mathbf{m})$ & $\mathbf{V}(\mathbf{m} / \mathbf{s})$ \\
\hline Pt 23 & AB 124 & 3.2 & 12.5 & 160 \\
\hline Pt 25 & & 3.2 & & \\
\hline Pt 26 & AB 125 & 3.5 & 11 & 154 \\
\hline Pt 27 & AB 105 & 5.5 & 4 & 88 \\
\hline Pt 28 & AB 128 & 3.1 & 8 & 100 \\
\hline Pt 30 & AB 127 & 3.8 & 20 & 304 \\
\hline Pt 31 & AB 134 & 3.4 & 13 & 177 \\
\hline Pt 32 & AB 129 & \multicolumn{4}{|c|}{ No clear Peak } \\
\hline Pt 33 & AB 126 & 2.9 & 15 & 174 \\
\hline Pt 35 & \multicolumn{5}{|c|}{ No clear Peak } \\
\hline Pt 36 & \multicolumn{5}{|c|}{ No clear Peak } \\
\hline Pt 37 & \multicolumn{5}{|c|}{} \\
\hline
\end{tabular}

Table 3: Soil properties used in Plaxis model.

\begin{tabular}{|l|l|l|l|l|l|}
\hline Soil Layer & $\begin{array}{l}\text { Cohesion } \\
(\mathrm{MPa})\end{array}$ & $\begin{array}{l}\text { Friction } \\
\text { Angle (de- } \\
\text { grees) }\end{array}$ & $\begin{array}{l}\text { Dilancy An- } \\
\text { gle } \\
\text { (degrees) }\end{array}$ & $\begin{array}{l}\text { Young } \\
\text { Modulus } \\
(\mathrm{MPa})\end{array}$ & $\begin{array}{l}\text { Poisson } \\
\text { Ratio }\end{array}$ \\
\hline Cemented Sand & 44 & 17 & 9 & 23 & 0.2 \\
\hline Clayey Sand & 26 & 25.8 & 13 & 25.6 & 0.2 \\
\hline $\begin{array}{l}\text { Marl \&lime- } \\
\text { stone }\end{array}$ & 28 & 24 & 12 & 43.5 & 0.2 \\
\hline Clay & 41 & 12.4 & 7 & 16 & 0.2 \\
\hline Marlstone & 33 & 24 & 12 & 62 & 0.2 \\
\hline Clayey Marl & 32 & 18 & 9 & 10 & 0.2 \\
\hline Sandy Clay & 41 & 12 & 6 & 25.6 & 0.2 \\
\hline Marl & 24 & 26 & 13 & 28 & 0.2 \\
\hline Sandstone & 5 & 30 & 15 & 24 & 0.3 \\
\hline
\end{tabular}

As a result, the most probable failure surface appears at the interface Clay/Marl. The top layer of clay is sliding as shown in figure 3 below.

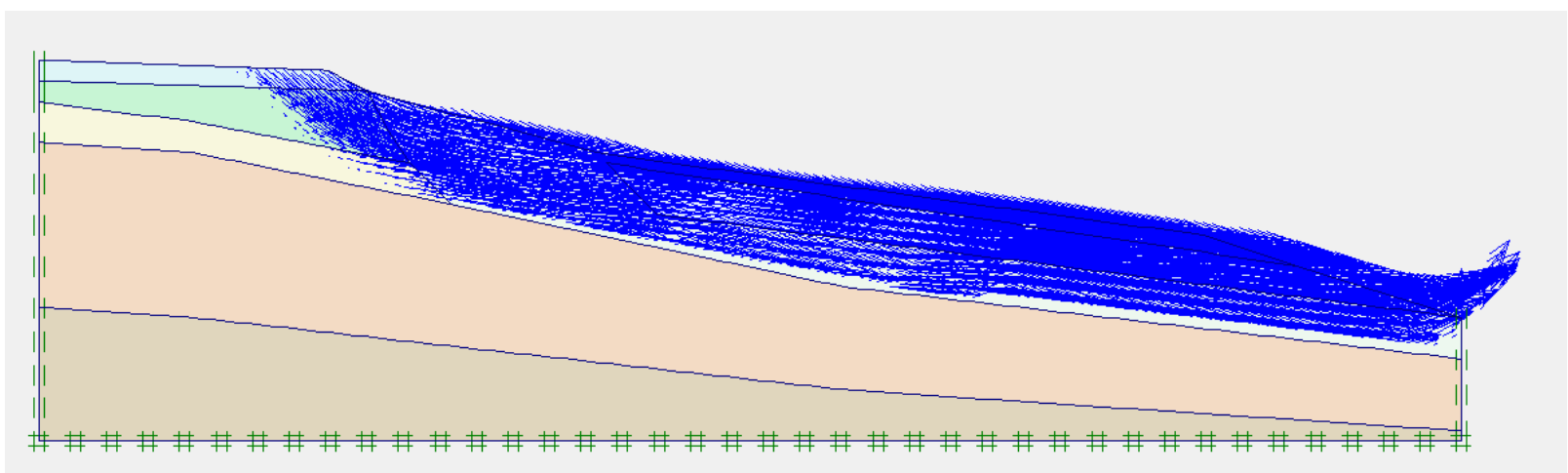

Figure 3: Failure surface of section $A$ - at the interface Marl and clay 
The initial conditions determined above reveal the state of the site at the time of soil investigation, where the slope is stable with a factor of safety of 2.9

In order to illustrate the state of the site where failure occurred, an interface is set at the top layer of Marl. This interface element will allow decreasing the mechanical properties of Marl at its interface with clay by choosing a suitable value for the strength reduction factor ( $\left.\mathrm{R}_{\text {inter }}\right)$. This factor relates the interface strength to the soil strength $\left(c_{i}\right.$ and $\varphi_{i}$, friction angle and cohesion) by:

$$
\begin{aligned}
c_{\mathrm{i}} & =\mathrm{R}_{\text {inter } \mathrm{X}} \mathrm{c}_{\text {soil }} \\
\tan \varphi_{\mathrm{i}} & =\mathrm{R}_{\text {inter }} \tan \varphi_{\text {soil }} \leq \tan \varphi_{\text {soil }}
\end{aligned}
$$

where $c_{\text {soil }}$ and $\varphi_{\text {soil }}$ are respectively the cohesion and friction angle of the soil.

A total collapse of soil is seen once Marl properties decreases $1 / 3$ as summarized in the following table:

Table 4: Mechanical properties of Marl interface.

\begin{tabular}{|l|l|l|}
\hline \multicolumn{2}{|c|}{ Initial conditions } & At Total failure \\
\hline Cohesion (kPa) & 28 & 10 \\
\hline Friction Angle (degrees) & 24 & 10 \\
\hline$R_{\text {inter }}$ & 1 & 0.3 \\
\hline F.S. & 2.9 & $\begin{array}{l}\text { Close to 1 (i.e. } \\
\text { Collapse) }\end{array}$ \\
\hline
\end{tabular}

As the soil properties at the time of slide triggering are unknown and after obtaining such results in the models, it is suspected that the main triggering factor is water. As we know, soils properties are affected by the presence of water especially the soils with very high fine contents (marl and clay). These soils lose an important part of their cohesion in the presence of water, reducing at the same time their shear strength.

Knowing that a 2D model do not represent accurately the failure shape and the complete behavior and heterogeneity of the site, a 3D model was conducted using FLAC ${ }^{3 \mathrm{D}}$ software. The soil is assumed to be composed by 3 layers: Clay, Marl and Sandstone in a Mohr Coulomb model with average values of soil properties obtained by geotechnical tests as shows the following figure. 
T. Matar ${ }^{1}$, F. Hage Chehade ${ }^{2}$, Jacques

$\mathrm{Harb}^{3}$, M. Rahhal ${ }^{4}$, D. Youssef Abdel Massih ${ }^{5}$, C. Abdallah ${ }^{6}$, E. Ibrahim ${ }^{7}$, L. Khalaf-Keyrouz ${ }^{8}$, G. Nasr ${ }^{9}$, G.

Abou-Jaoude ${ }^{10}$, and A. Sursock ${ }^{11}$

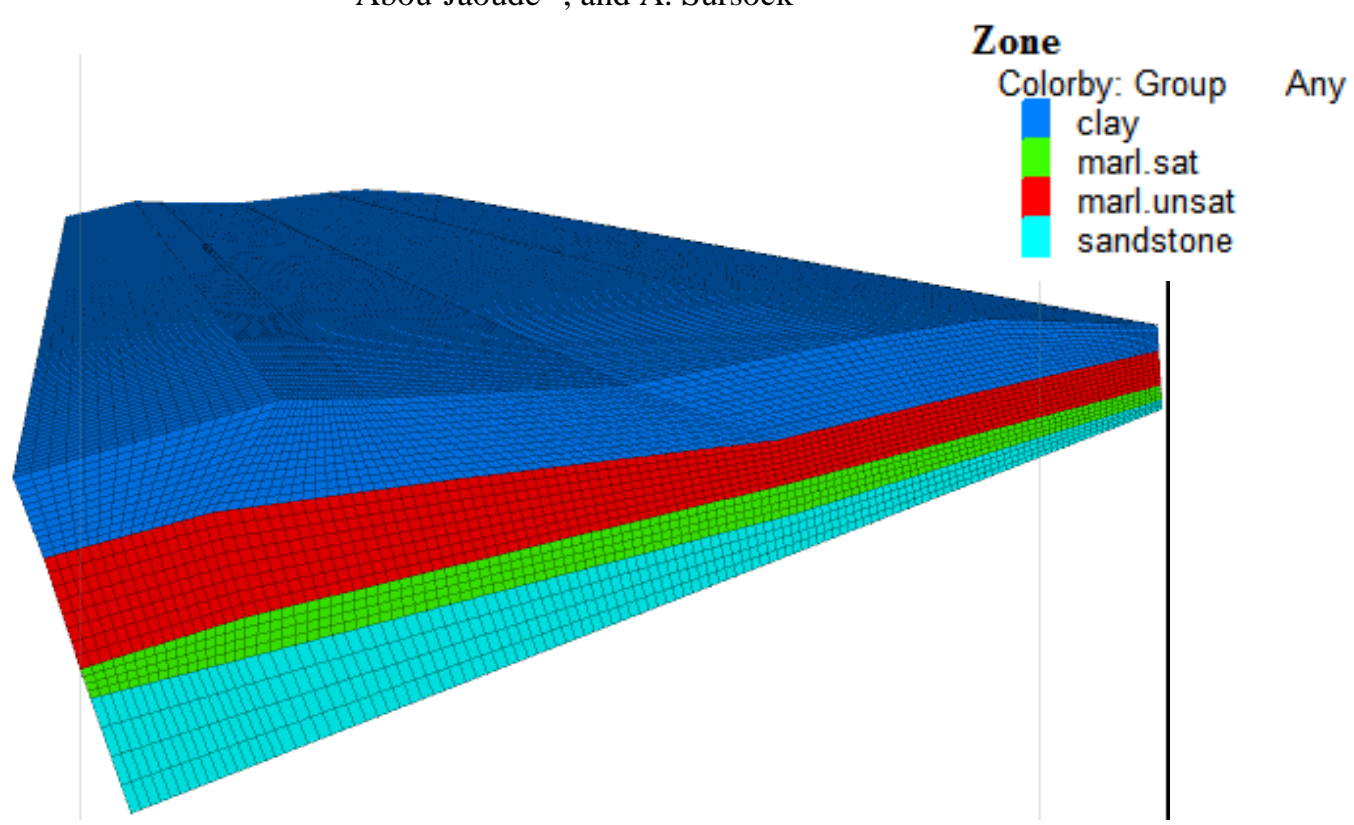

Figure 4: FLAC ${ }^{3 D}$ static model

After using the shear strength reduction technique to determine the 3D slope safety factor, the failure surface obtained is the same as the one in the 2D section A, at the interface of Marl and Clay as shown in figure 5.

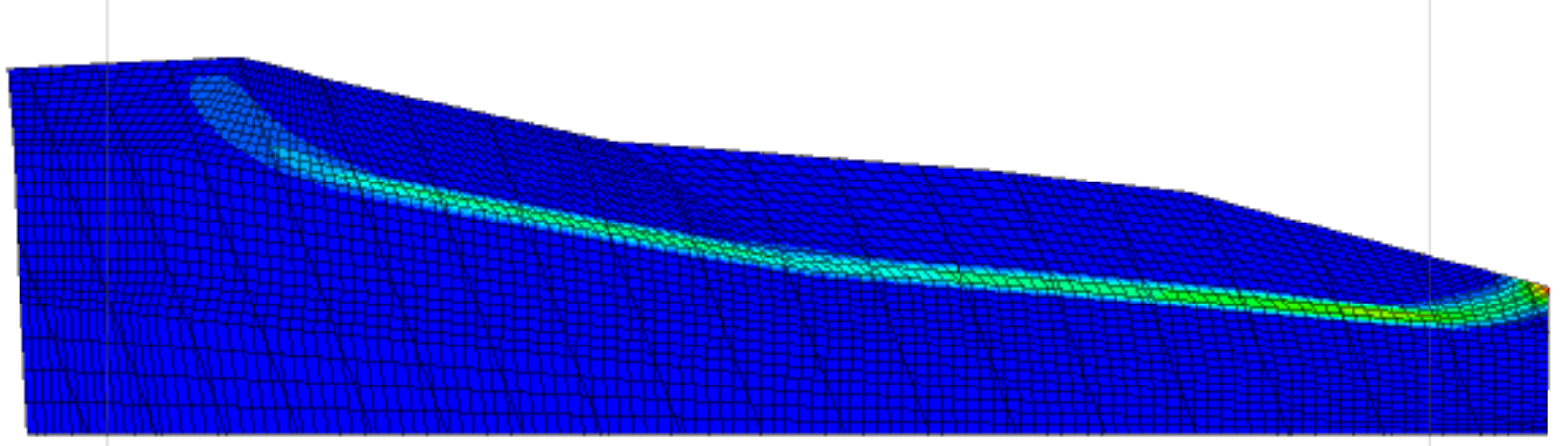

Figure 5: Section showing Failure surface of the 3D model

The safety factor of the slope in 3D model is 3.25 which is close to the one obtained by the 2D model (equal to2.9). So it can be concluded that the 3D model confirmed the results already found in the $2 \mathrm{D}$ model.

\section{DYNAMIC ANALYSIS ON THE SITE}

For the dynamic model, the same soil properties, water table level, boundary conditions and initial stresses are considered.

A mesh of $0.5 \mathrm{~m} * 0.5 \mathrm{~m} * 0.5 \mathrm{~m}$ is used, satisfying the condition that the dimension of an element should not exceed $\lambda / 10$, where $\lambda$ is the minimal wavelength. $\lambda=\mathrm{Vs}_{\min } / \mathrm{f}_{\max }$ where $\mathrm{Vs}_{\min }$, the smallest shear wave velocity is $88 \mathrm{~m} / \mathrm{s}$ and $\mathrm{f}_{\max }$ the maximum signal frequency is $20 \mathrm{~Hz}$. 
As for dynamic boundaries, free field conditions are applied to lateral boundaries and quiet boundaries at the base in order to reduce wave reflections and model a half space at the base. Dynamic input is applied to the model using a table signal with a time step of $0.01 \mathrm{~s}$ and a frequency varying from 1 to $20 \mathrm{~Hz}$. This table is converted in stresses to apply a velocity wave in the horizontal plane according to the following equation:

$$
\sigma_{\mathrm{s}}=2\left(\rho \mathrm{V}_{\mathrm{s}}\right) \mathrm{Vs}
$$

Eq.4

where: $\sigma_{s}=$ applied shear stress

$\rho=$ mass density of the bedrock

$\mathrm{V}_{\mathrm{s}}=$ speed of s-wave propagation of the bedrock

$\mathrm{v}_{\mathrm{s}}=$ input shear particle velocity

and $\mathrm{V}_{\mathrm{s}}$ is given by:

$$
\mathrm{V}_{\mathrm{s}}=\sqrt{ }(G / \rho)
$$

where $\mathrm{G}$ is the shear modulus of bedrock.

Note that the input signal is a delta like signal of flat spectrum as shown in figure 6 , in order to be able to observe clearly the amplification response for all frequencies ranging between 1 and $20 \mathrm{~Hz}$.

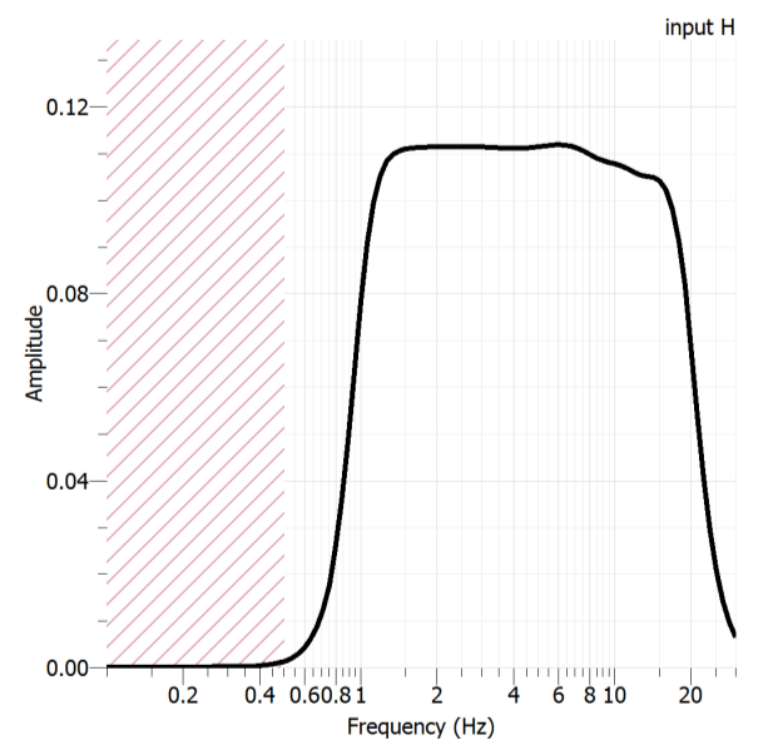

Figure 6: input spectrum

The shear wave velocity is plotted for 7 selected points. The time step of the dynamic output is $0.00172 \mathrm{~s}$ as calculated by FLAC ${ }^{3 \mathrm{D}}$. The output velocity is re-sampled in order to obtain the response with the same time step as the input signal. The figures below show the velocity spectrum of points A, B, C, D, E, F and G (cf. Figure 7) in X, Y and Z directions. 
T. Matar ${ }^{1}$, F. Hage Chehade ${ }^{2}$, Jacques

$\mathrm{Harb}^{3}$, M. Rahhal ${ }^{4}$, D. Youssef Abdel Massih ${ }^{5}$, C. Abdallah ${ }^{6}$, E. Ibrahim ${ }^{7}$, L. Khalaf-Keyrouz ${ }^{8}$, G. Nasr ${ }^{9}$, G. Abou-Jaoude ${ }^{10}$, and A. Sursock ${ }^{11}$

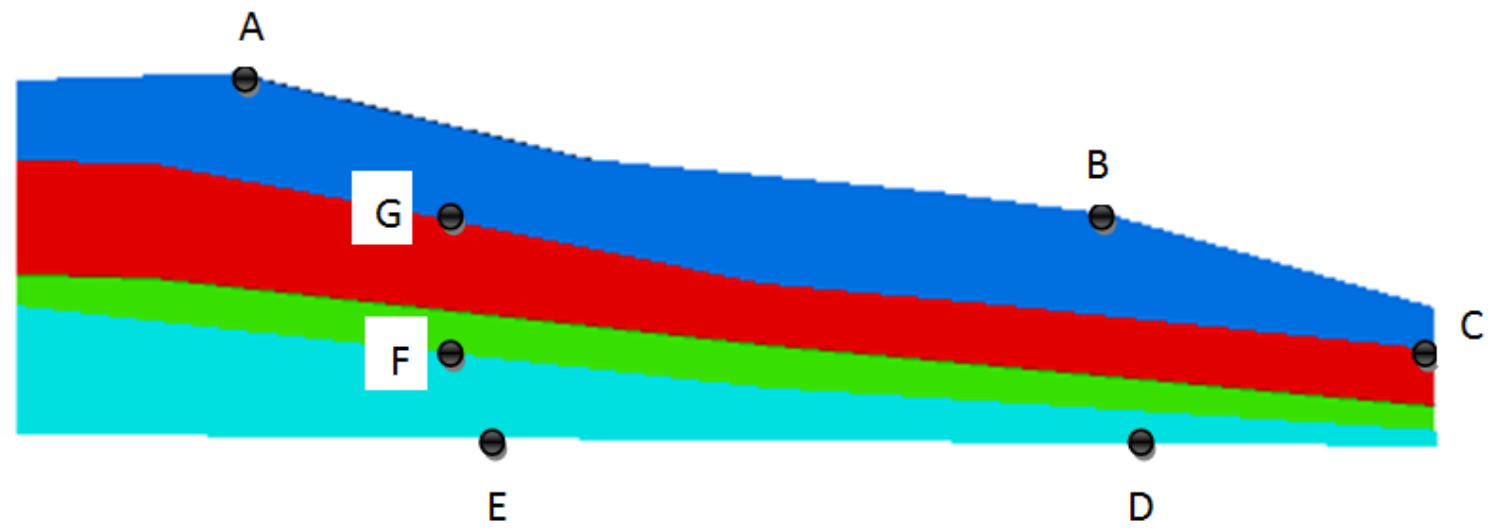

Figure 7: Selected points

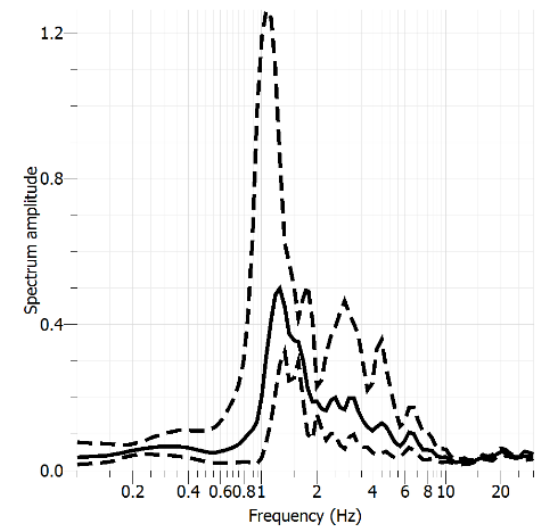

Figure 8: point A spectrum

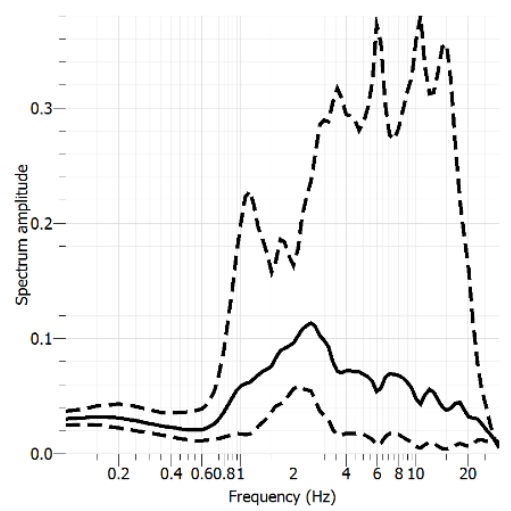

Figure 10: Point D spectrum

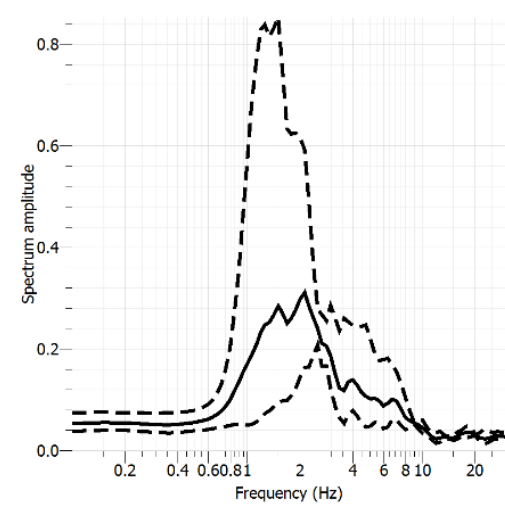

Figure 9: Point B spectrum

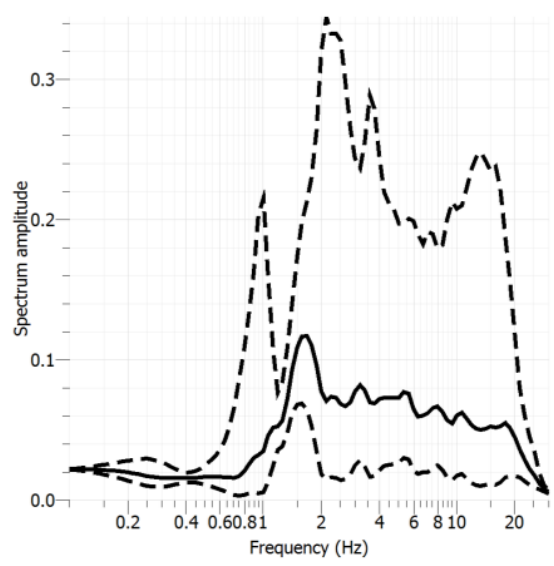

Figure 11: Point E spectrum 


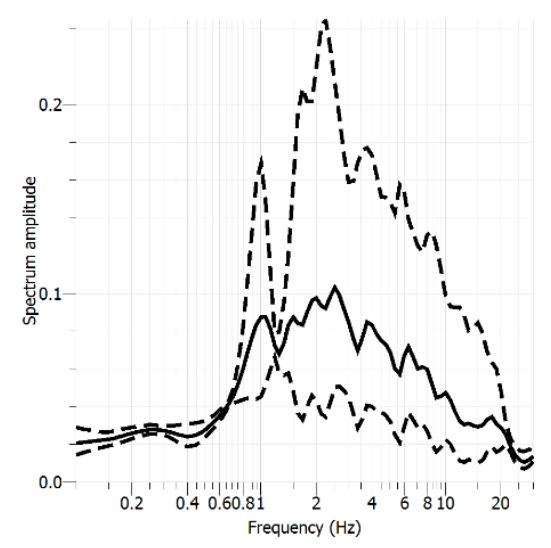

Figure 12: Point F spectrum

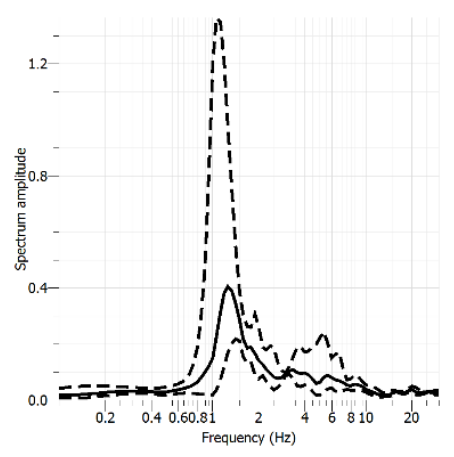

Figure 13: Point G spectrum

One can notice that at points A, B and G (Figures 8, 9 and 13), a first amplification between 1 and $2 \mathrm{~Hz}$ and a second amplification between 3 and $4 \mathrm{~Hz}$. The first amplification may be caused by an industrial activity (confirmed by the H/V tests) and the second amplification matches well with the natural frequency found in the geophysical test. The results indicate the importance of understanding the role of soft material, especially clayey soils, in amplifying soil movements whenever this type of soils is found on top of a more rigid formation which is in our case sandstone. For points D, E and F (Figures 10, 11 and 12) at proximity of sandstone, no clear peak is observed.

After comparing the spectrums of points A and B in horizontal direction with the input signal spectrum, it is found that an important amplification is obtained between 0.1 and $8 \mathrm{~Hz}$.

As a conclusion, the results of the dynamic analysis were in good agreement with the frequencies obtained by the $\mathrm{H} / \mathrm{V}$ tests and have shown high amplification for a wide frequency range.

\section{CONCLUSIONS}

In this paper, an integrated geo-assessment is conducted on Dahr El Baidar slope - Lebanon that hosts a section of the Arab Highway under construction. The geological analysis shows the presence of faults in the vicinity as well as a layer of weak clay at the surface. The geotechnical investigation is based on the interpretation of 7 boreholes. Geophysical tests are performed using ambient noise vibration technique based on the HVSR method. The analysis of soil data based on the cross sections reveals a high fine percent, and fine soils loose an important part of their cohesion in the presence of water, due to the reduction of their shear strength. It is suspected that the failure is probably induced at the interface of two materials with different rigidities or within a soft material itself. Similarly, the dynamic analysis reveals that the natural frequency found by the geophysical tests is accurate and there is an important amplification at the surface once a dynamic wave is applied. 
T. Matar ${ }^{1}$, F. Hage Chehade ${ }^{2}$, Jacques

Harb $^{3}$, M. Rahhal ${ }^{4}$, D. Youssef Abdel Massih ${ }^{5}$, C. Abdallah ${ }^{6}$, E. Ibrahim ${ }^{7}$, L. Khalaf-Keyrouz ${ }^{8}$, G. Nasr ${ }^{9}$, G.

Abou-Jaoude ${ }^{10}$, and A. Sursock ${ }^{11}$

Further analysis is needed to evaluate the slope failure under earthquake loading and additional geophysical tests are also necessary to better estimate the dynamic properties of the soil. Scenarios of the different cross sections will be examined later to determine the static and dynamic failure surfaces and examine the triggering factors behind the slope instabilities.

\section{ACKNOLEDGMENT}

This work is part of the assessment and prediction of the behavior of various critical slopes in Lebanon carried by RUMMARE, a Research Unit on Mass Movement hazard Assessment and Risk Evaluation grouping researchers from major universities and research centers in Lebanon. The contributions of graduate students Akram Ghsossoub and Anthony Fayad should be acknowledged. The RUMMARE researchers would like to thank the Lebanese National Council for Scientific Research for funding this unit.

\section{REFERENCES}

[1] Abdallah, C., Chorowicz, J., Bou Kheir, R., Khawlie, M., 2005. "Detecting major terrain parameters relating to mass movements' occurrence using GIS, remote sensing and statistical correlations, case study Lebanon." Remote Sensing of Environment, 99, 448-461.

[2] Abdallah, C., Chorowicz, J., Bou Kheir, R., Dhont, D., 2007. "Comparative use of processed satellite images in remote sensing of mass movements: Lebanon as a case study." International Journal for Remote Sensing, 28:19, 1 - 20.

[3] Dubertret, L., (1945). "Geological Map of Zahlé, 1/50,000. " Ministry of National Defence-Geography Department, Lebanon.

[4] Dubertret, L. (1960). "Carte Géologique au 50000 Feuilles de Hermon." Institut Geographique National, Beirut, Lebanon

[5] Khawlie, M. (2000). "L'environnement du Liban : une ressource perdue (en arabe)." Menrikh publisher, 372p.

[6] Khawlie, M., and Hassanain, H. (1984). "Failure phenomena and environmental control of the relatively unstable Hammana area, Lebanon." Engineering Geology, 20, 253-264.

[7] Khawlie, M., Ghalayini, I., (1985). "Geological evaluation of marls in relation to their mass behavior, Achrafieh area, Beirut." The Lebanese Science Bulletin, 1(1), 83-98.

[8] Khawlie, M., A'war, R., (1992). "Terrain evaluation for assessment of highways in the mountainous eastern Mediterranean of Lebanon." Bulletin of the international association of engineering geology, 46, 71-78.

[9] Khawlie, M., Touma, G., (1993). "Determining the behavior of the highly variable basal cretaceous sandstone (Nubian Facies) in Brummana Lebanon." Lebanese Science Bulletin, 6(1), 33-45.

[10] Konno, K. and T. Ohmachi, (1998). "Ground-motion characteristics estimated from spectral ratio between horizontal and vertical components of microtremor." Bulletin of the Seismological Society of America, 88(1), 228-241. 
T. Matar ${ }^{1}$, F. Hage Chehade ${ }^{2}$, Jacques

$\mathrm{Harb}^{3}$, M. Rahhal ${ }^{4}$, D. Youssef Abdel Massih ${ }^{5}$, C. Abdallah ${ }^{6}$, E. Ibrahim ${ }^{7}$, L. Khalaf-Keyrouz ${ }^{8}$, G. Nasr ${ }^{9}$, G. Abou-Jaoude ${ }^{10}$, and A. Sursock ${ }^{11}$

[11] Nakamura,Y., (1989). "A method for dynamic characteristics estimation of subsurface using microtremors on the ground surface." Quarterly reports of the Railway, Technical Research Institute, Tokyo, 30, 25-33.

[12] Nogoshi M. and Igarashi T. (1971). "On the amplitude characteristics of microtremor." Journal of seismological Society of Japan, 24, 26-40.

[13] Rahhal, M.E., Nini, R., Favre, J.L. (2003) Analysis of Factors Causing Slope Instabilities, Proceedings $56^{\text {th }}$ Canadian Geotechnical Conference, Winnipeg, Manitoba, CANADA, Volume 2: pages 368-375.

[14] Rahhal, M.E. (2014) The Factor of Safety in Slopes under Earthquake loading, Geo Congress 2014- Atlanta USA, ASCE Geotechnical special Publication No 234: pages 12741283.http://dx.doi.org/10.1061/9780784413272.124

[15] Rahhal, M., Youssef Abdel-Massih, D., Harb, J., Hage-Chehade, F., Abdallah, C., Khalaf-Keyrouz, L., Abou Jaoude, G., Ibrahim, E., Nasr, G., Sursock, A. (2014). Modelling Dahr El Baidar Slope with integrated geo-assessment, Proceedings, Second European Conference on Earthquake Engineering and Seismology, Istanbul, TURKEY, August 2529, 2014.

[16] Sadek S., M. Bedran, and I. Kaysi (1999) "A GIS Platform for Multi-Criteria Evaluation of Route Alignments," Journal of Transportation Engineering, Vol. 125 No.2, pp. 44152.

[17] Tavitian, C. (1974). "Clay mineralogy and geotechnical properties of cretaceous clayshales in Lebanon." Ph.D. thesis, University of Salford, 247p.

[18] Vermeer P.A. \& Brinkgreve R.B.J. "PLAXIS Finite element code for soil and rock analyses", version 7, Rotterdam : Balkema (1998).

[19] Wathelet, M., D. Jongmans, M. Ohrnberger, and S. Bonnefoy-Claudet (2008). "Array performances for ambient vibrations on a shallow structure and consequences over Vs inversion." Journal of Seismology, 12, 1-19.

[20] Youssef Abdel Massih D., Soubra, A.H., Harb J. \& Rouania, M. (2010). "Dynamic slope stability analysis by a reliability-based approach." Fifth International Conference on Recent Advances on Geotechnical Earthquake Engineering and Soil Dynamics, San Diego, California, May 24-29 2010,10p.

[21] Youssef Abdel Massih D., Soubra A.-H. and El-Hachem E. (2007). "Slope stability analysis in seismic areas by a reliability approach". 4th International Conference on Earthquake Geotechnical Engineering (4ICEGE), Thessaloniki, Greece, 25-28 June, 12p. 